\title{
NFUD Symposium 2015 på Røros
}

\section{5. - 17. april}

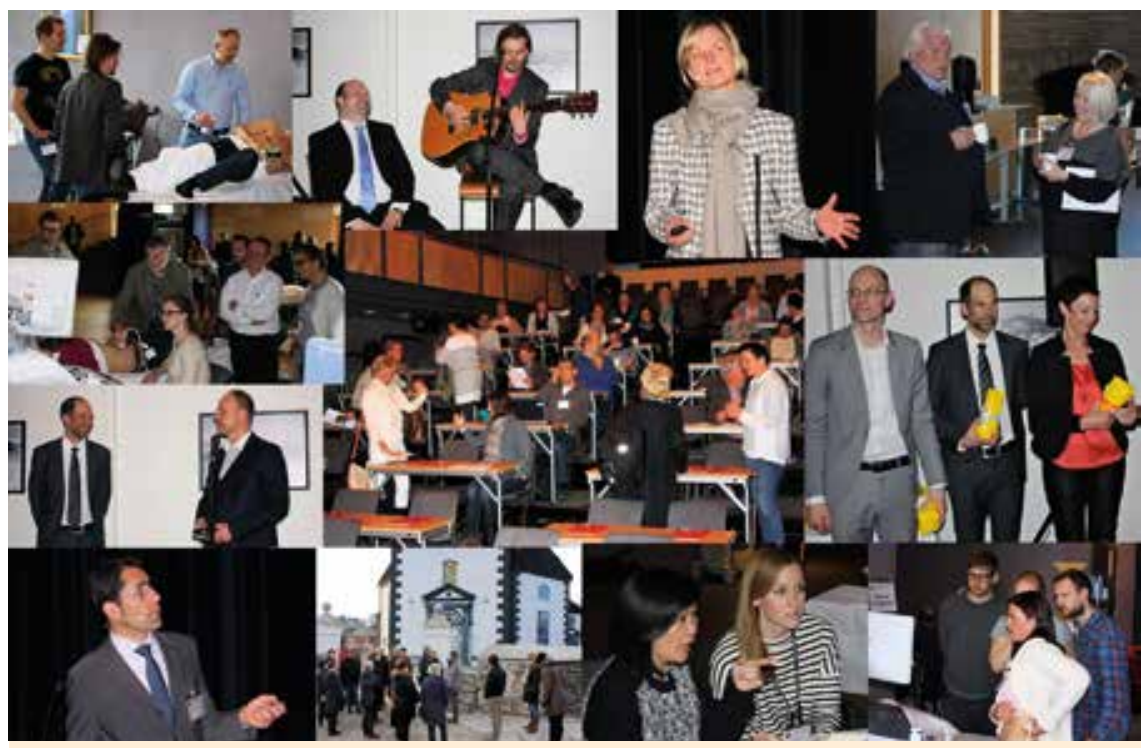

Fig. 1 Inntrykk fra NFUD symposium 2015 på Røros.

I år var Røros møtested for NFUD symposiet. De 99 registrerte deltakerne, som fant veien dit, kunne nyte et faglig og sosialt vellykket arrangement i en unik og samtidig profesjonell omgivelse.

Etter at det i de siste årene har vært fokus på praktiske øvelser på onsdag ettermiddag, ble det $\mathrm{i}$ år for første gang gitt et eget kurstilbud på onsdagen, „Basalkurs i ultralydfysikk og apparatlære“. Tilbudet ble godt mottatt og tilbakemeldingene var stort sett positive. Forslag til forbedring kommer styret til å ta hensyn til ved planlegging av fremtidige kurs.

Som vanlig belyste både utenlandske og norske forelesere aktuelle tema rundt allmenn- og akuttmedisin, indremedisin, muskelskjelett, gynekologi og obstetrikk og radiologi.

Generalforsamlingen måtte i år velge ny leder og flere styremedlemmer. Roald Flesland Havre, som ledet foreningen de siste 4 år ikke bare faglig suverent, men snudde også en vanskelig økonomisk situasjon til en solid finansiell basis, kunne ikke velges igjen. Det samme gjald også nestleder og sekretær Eva Tegnander, som har med sin presisjon og nøyaktighet preget foreningens arbeid gjennom mange år.
Også Rune Hansen, som hadde ansvaret for NFUD sin nettside, og Vivi Bakkeheim, som var utmerket konstruktiv og effektiv i sitt bidrag til styrets arbeid, stod ikke til gjenvalg.

Ny leder ble Nils Petter Oveland, anestesilege og akuttmedisiner ved Stavanger Universitetssjukehus og Universitet i Stavanger. Ny nestleder og sekretær er Kari Utne, jordmor ved Stavanger Universitetssjukehus. Dessuten ble Morten Glasø, allmennlege i Rælingen, Anette Hem Johnsen, jordmor ved Sørlandet sykehus Arendal, Kim Nylund, gastroenterolog ved Haukeland sykehus, Sigrid Berg, sivilingeniør ved NTNU/SINTEF, Ruth Stoklund Thomsen, revmatolog ved St. Olavs hospital og Dan Skoglund, medisinstudent valgt inn i styret. Styret har dermed 11 medlemmer. Nærmere informasjon om nytt styret kommer i Flaggermusen 4/2015 og på nettsiden.

Generalforsamlingen fikk også presentert en ny nettside, som skal erstatte den gamle i løpet av juni 2015.

Festmiddagen var ikke bare preget av taler rundt det av- og påtroppende styret, men også av både planlagte og spontane underholdende innslag.
Alexander Mathiessen fikk prisen for beste frie foredrag i form av 10000 NOK for sitt innlegg „Ultrasound-detected inflammation predicts radiographic progression in hand osteoarthritis (OA) after five years".

NFUDs forskningsstipend på 10000 NOK ble tildelt Hilde Løland von Volkman for sitt prosjekt „Fluid overload and motility disturbances in the small intestine - Characterization of the effects of an activating GUCY2C mutation - an investigation with SmartPill and gastrointestinal ultrasonography before and after a meal provocation“.

Bilder fra symposiet kommer på NFUDs nettside http://www.nfud.no/.

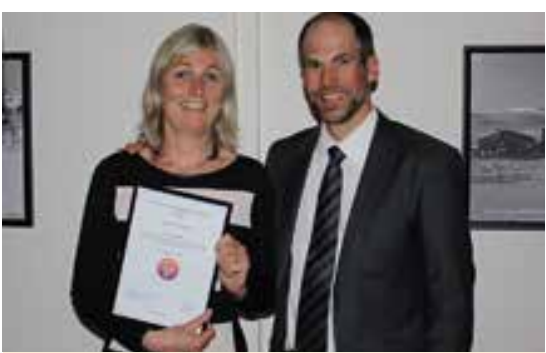

Fig. 2 NFUDs forskningsstipend fikk Hilde Løland von Volkman (v.)

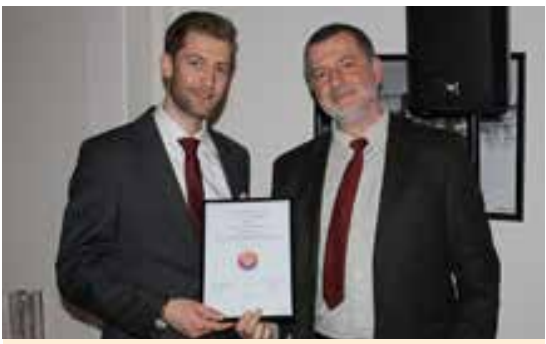

Fig. 3 Pris for beste frie foredrag fikk Alexander Mathiessen (v.)

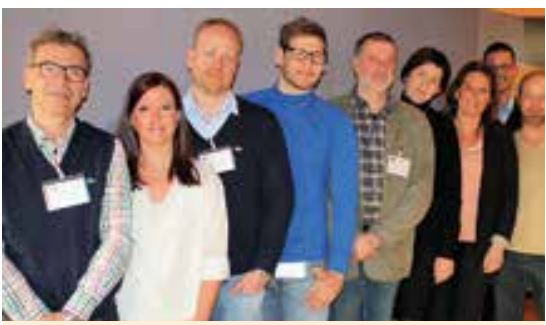

Fig. 4 Det nye NFUD styret: Morten Glasø, Beatrice Rüger, Nils Petter Oveland (leder), Dan Skogland, Thomas Reiher (kasserer), Kari Utne (nestleder), Anette Hem Johnsen, Peter Montzka og Kim Nylund. Sigrid Berg og Ruth Stoklund Thomsen er ikke med på bilde. 